\title{
Conceptual Understanding Of Mathematics Lesson With Classical Guidance Tutorial As A Final Examination Preparation On Grade 6 Lentera Harapan Elementary School- Tomohon
}

\author{
D Nainggolan ${ }^{1}$ \\ ${ }^{1}$ Universitas Negeri Manado, Indonesia \\ corresponding author: deklaynainggolan@unima.ac.id
}

\begin{abstract}
The research aim is to know how is the conceptual understanding of mathematics lesson with classical guidance tutorial as a final examination preparation on grade 6 Lentera Harapan Elementary School- Tomohon. The research was done by descriptive methods, with two (2) classes of Grade 6 students Lentera Harapan Elementary School- Tomohon. Data was collected through interviews and tests. Data analysis by using percentage of $40 \%$ students can get $6.5 \mathrm{KKM}$ score (a minimum completeness criteria). This researches shows that in general student conceptual understanding of mathematics lesson is not satisfying. This is visible from $40 \%$ students of Grade 6 can understood the mathematics concept and $60 \%$ still struggling with the concept. The researcher discovered that there were misconception on fraction and memorizing on the units of length, time, weight and temperature and how to convert it on difference unit.
\end{abstract}

Key words: Understanding, concept, mathematics

\section{Introduction}

Mathematics is a core subject in Elementary school which must be taught in every level. It is because the subject will be learning in the upper level school as well. It becomes one of the subjects tested on elementary final examination. Learning mathematics also important in life, not only because as a school subject, but also used for students in their daily chorus such as shopping groceries, calculating money, time, etc. It is important students can link content and practice standards as a means to strengthen understanding. [2] It mean that if a student learns about a particular topic of math at school, he must connect it to his life practice so he can understand more both the lesson taught and also the chorus that uses math.

In Grade six, students learn vary topics, some of them are new topics but many of the topics are extended from their previous lesson. Some of the students can understand the math concept in grade six easily because of their previous math concept stayed. But the others not only struggling with learning new things but also did not understand about the basic concept. In grade six, many of the mathematical 
concepts will shows in a word problems questions, for some students that only memorizing the formula without understanding how to use the formula in a word problems questions, they will think that a word problems questions is a night mare. But for those whose understand the mathematics formula Mathematical word problem give students challenges in applying mathematical thinking in various situations. For example, a problem about how far a bicycle can travel at a certain speed and another problem with a scenario involving a spaceship might appear to be very different - but at their core are similar rate problems. The solving requires integration of some cognitive processes in which the students need to understand the language and factual information in the problem, translate the problem by using relevant information to create the appropriate mental representation, compile and monitor problem-solving plans, and carrying out appropriate procedural calculations. [5] Can offline metacognition enhance mathematical problem solving? In addition, knowledge in mathematical word problem can give students confidence to accomplish the task. The lack of strategy in mathematical word problem can decrease the confidence and belief of being success. The success of students in mathematical word problem is supported by psychological factors, not only about the method of learning but also about the beliefs about the ability possessed by students. The beliefs that the students have in performing a particular task or action is called self-efficacy. [1]

Math word problems have traditionally been problematic for many students. A student may read two problems and believe them to be different because of the language and situation presented.. Through schema-based instruction, we help the student focus on the underlying problem structure and represent the problem text using visual schematic diagrams that show how quantities in a word problem are related.[6]

Based on the background, researcher is willing to do the research on "Conceptual Understanding Of Mathematics Lesson With Classical Guidance Tutorial As A Final Examination Preparation On Grade 6 Lentera Harapan Elementary SchoolTomohon".

With this research we will discovered:

1. How is the students understanding for math's lesson for grade 6 ?

2. Is there any misconception of math's lesson among the students?

The objectives of this research are to clearly and objectively knows the conceptual understanding of Mathematics Lesson, especially for their final examination.

In learning math, the basic conceptual understanding is very important to solving problems. Conceptual understanding is a learning process, because with the conceptual understanding students can develop their ability for every lesson they learn. Conceptual understanding consists of two words, which are Understand and concept. [3], understanding is way to possess something with your mind. This also said understanding is a standard tools in an education program which reflecting competencies or abilities to deliver students to have competencies in knowledge.[4] While the concept is a category of stimuli that have general characteristics. 
From the above opinion we conclude that conceptual understanding is possessing knowledge with our mind which consists of stimule.

\section{Methods}

This research use Descriptive methods. Data collected by interviews and tests. Instruments for interviews through questionnaire and tests. The questionnaire consists questions or statements about conceptual understanding of mathematics topics. Population of the researches is grade 6, Lentera Harapan elementary schoolTomohon. Sampels are 48 students.

\section{Results and discussion \\ Results}

Learning outcomes data presented on table 1.

Table1. Score test result

\begin{tabular}{|c|c|c|}
\hline SCORE & TEST 1 & TEST 2 \\
\hline 0 & $10 \%$ & $0 \%$ \\
\hline $10-20$ & $27 \%$ & $17 \%$ \\
\hline $30-40$ & $18 \%$ & $17 \%$ \\
\hline$>40$ & $45 \%$ & $64 \%$ \\
\hline
\end{tabular}

On test 1 , tutor gives 40 multiple choice questions which are consisted of 12 grade 6 math topics, $80 \%$ of the topics are presented as a word problem. From the result on Table 1 shows that there are $10 \%$ of students whose join the tutorial class still struggling with their test, none of their answers correct. Those students not only couldn't answer the word problems questions but also miscounting for direct questions. Some of them said they are too nervous about the test and worried they cannot answer the questions. From test 1 we also see that there are more students that very low in math, from percentages we can figure that $55 \%$ students got score below 40. From 66 students in grade 6, 48 students join the tutorial class, and 55\% of them got scores below 40 out of 100 .

On test 2, tutor also gives 40 multiple choice questions which are consisted of 12 grade 6 math topics, $80 \%$ of the topics are presented as a word problem too. From the result we can see that students confidence are built up, none of them got zero score, for levels of scores also slightly changing. $64 \%$ of students can got above 40 score. 
Students' attendances on tutoring presented on table 2.

Table2. Students' attendances

\begin{tabular}{|c|c|}
\hline DAY & PERCENTAGES \\
\hline 1 & $100 \%$ \\
\hline 2 & $42 \%$ \\
\hline 3 & $46 \%$ \\
\hline 4 & $50 \%$ \\
\hline 5 & $54 \%$ \\
\hline 6 & $30 \%$ \\
\hline 7 & $38 \%$ \\
\hline 8 & $35 \%$ \\
\hline
\end{tabular}

The result on table 2, shows students attendances during the tutorial class. The result shows that tutorial class after school is not students' favorite. Only on Day 1, 100\% joined the class, Day 2 until Day 8 maximum $54 \%$ of students attended. Even though there is a strange fact that after Day 1, Day 2 and Day 3 attendance decreasing until $42-46 \%$ then rises again $50-54 \%$ then continues decreases until the last Day only $35 \%$ students attended the tutorial class.

\section{Discussion}

From the tests, students who's got scores $>40$ from multiple choice questions are 45-64\%. Based on the research can be concluded that a Conceptual understanding of Grade 6 students Lentera Harapan Elementary School in general are not satisfying, because even though the tutorial given intensively, but lack of students willingness to join the tutorial classes. Students who attended more classes did better in assessment and that attendance was better in smaller classes and in classes which were taught by permanent staff. Therefore although attendance is problematic, it is a symptom of a deeper malaise. Students who are more interested in the material, or more skilled academically, or more focused are almost certain to attend class more often than student who are less interested, less skilled, or less focused. If this is the case, then the results to some extent reflect a general impact of motivation on performance rather than a true effect of attendance[10]. Attendance was higher in classes where absenteeism was penalized and, again, that higher attendance led to better exam results; earlier research revealed that absenteeism was higher on Fridays and increased as the semester progressed [8]. Attendance alone does not guarantee good results; those who attend and participate in lectures and tutorials do better than those who simply turn up. The most common reasons for nonattendance included sickness, being too busy, or having to do paid work.[9].

Beside students' attendances issue, mathematical concepts also take places to impact students tests performance. On the tutorial given, tutor presented the modeling as one way to solve the problems.[7]. Some students found this method is not only fun but easy to use because it is really visually shown the problem and the solution as well. Topics of math can use modeling for conceptual understanding, 
such as fraction, units of time, weight, speed, scales, geometry, etc. Many teachers at school rarely use the modeling method because they are limited in equipment such as Projector and props. In the other hand if teachers use this methods to teach math, it will significantly increasing students math ability performance.

\section{Conclusion}

From the research, we can conclude that Students understanding of mathematical concept are still weak, especially with the word problems questions. Included topics such as Units of Time, Money, Length, Weight, etc. Students also couldn't understand Fraction topics, included how to adding two or more fractions with different denominators, how to converting regular/ basic fraction into percentages or decimals form. There are misconceptions of math word problems in order to solve it, some students are making it more difficult.

To all grade 6 teachers hopefully can prepare their students in advance, especially if they already knows their students ability on mathematics. Grade 6 Teachers also must know the tricks to be taught to students about solving the math problems in a limited time, because final examination is limited by time. Asking help from parents or other qualified people to help tutoring the students on the after school time.Asks students to collect the final exams for the previous 5 years, and asks them to practice at home.

\section{References}

[1] Bandura A 1995 Self-efficacy in changing societies. Cambridge: Cambridge University Press. 334

[2] Confrey, Jere, and Erin E. Krupa. 2010. Curriculum Design, Development, and Implementation in an era of common care state standards: Summary Report of a conference. Arlington, Va.: Center for the study of mathematics curriculum.

[3] Danim Sudarwan. 2010. Pengantar Kependidikan. Bandung: Alfabeta.

[4] Daryanto dan Farid M. Konsep Dasar Manajemen Pendidikan Di Sekolah. Yogyakarta: Gava Media. 2013

[5] Desoete A, Roeyers H, and De Clercq A. 2003. Can offline metacognition enhance mathematical problem solving? Journal of Educational Psychology. $188-200$

[6] https://cehdvision2020.umn.edu/blog/creating-better-strategies-teaching-mathword-problems/

[7] National Research Council's. 2001. Adding it up.Serve as a foundation for Grades K-12mathematics instruction. The common core state standards for Mathematics.

[8] Marburger, D. 2006. Does mandatory attendance improve student performance? Journal of Economic Education, 37 (2), 148-155.

[9] Massingham, P. \& Herrington, T. 2006. Does attendance matter? An examination of student attitudes, participation, performance and attendance. Journal of University Teaching and Learning Practice, 3 (2), 82-103. 
Journal of Educational Method and Technology Vol. 2 No. 1, April 2019

P-ISSN 2622-8459 E-ISSN 2622-8467

http://ejournal.unima.ac.id/index.php/jemtec

[10] Romer, D. 1993. Do students go to class? Should they? Journal of Economic Perspectives. 167-174 